\title{
Public Health and the Pre-Modern City: A Research Agenda
}

G. Geltner*

University of Amsterdam

\begin{abstract}
How and to what extent did pre-modern people go about creating healthier environments? Can we reasonably talk about public health when it comes to earlier urban societies? This essay briefly surveys a few tenacious misconceptions about preventative (as opposed to curative) health care in pre-modern cities, and then proceeds to review a budding scholarly literature that explores how urban dwellers, organizations, and governments, especially in medieval Europe and the Near East, identified and addressed the particular health risks attendant upon their milieus. The article concludes by pointing out several fruitful directions in which this emerging historical field can develop.
\end{abstract}

Medieval cities are often viewed as environmental accidents waiting to happen. "The visual virtues of medieval towns", reckons one textbook, "were grimly offset by the dismal ineptitude of public health services and municipal control over the environment ... Squalor, dirt, discomfort and disease were the accepted lot of medieval man". 1 And an influential survey of preindustrial cities imaged them quite literally as growing heaps of dung. ${ }^{2}$ Yet even our modest familiarity with earlier approaches to public health, above all in cities, is beginning to point in a rather different direction, namely that successfully managing its diverse, crowded, and turbulent urban population is perhaps the greatest unsung achievement yet of medieval civilization.

In some ways, this should come as no surprise. As Patricia Crone has remarked, urban societies across the pre-industrial world had the advantage of being politically well-organized, the implication being that control over various aspects of life, including the regulation of public health, was not only more needed but also more feasible there than in the countryside. ${ }^{3}$ Thus, the fact that urban societies committed resources to healthscaping - improving health at a population level, often with an emphasis on physical intervention - was a matter of choice rather than mere capacity. And yet it seems that the bar some scholars have set for these civilizations' health-related accomplishments has been low. Even those few historians of public health who were sympathetic to the challenges of earlier periods, such as George Rosen, have identified the development of quarantine, hospitals, and practices of poor relief as "all the more impressive when one recalls that they were undertaken in a world in which superstition was rampant and much of the scientific knowledge required for the effective handling of health problems was absent". 4 The problem with this ostensibly balanced view is that it is blurred by the author's quest for precursors to modern epidemiology, an approach still shared by many historians of public health and social medicine. Samuel Cohn, for instance, a distinguished historian of medieval Europe, argued that, prior to the late 16th century, physicians mostly neglected to address population-level concerns, by which he means plague. 5 
The epidemiological focus, however, has been called into question by several scholars of the pre-industrialized world, who, on the one hand (and much like Cohn), see ameliorist narratives of Enlightenment and progress as an obstacle to understanding earlier preventative measures on their own terms; and, on the other, have adopted a broader definition of public health, one transcending the containment of plague. In this essay I will briefly trace how this more recent claim had emerged and suggest some ways in which it can be further substantiated or at the very least tested.

\section{Converging Historiographical Challenges}

As in many other respects, so in the history of public health, the medieval period is commonly seen as one of inactivity or decline. As recent research has shown, however, ancient Athenians' responses to plague and disease merely scratched the surface of staple health interventions: they implemented no quarantine, created no sanitary corridors, evacuated no populations, purified no air, and mobilized only partially to remove and dispose of corpses - all of which, as we shall see, were staple measures applied in many medieval cities. ${ }^{6}$ Small wonder, then, that conceptions of the city as an inherently diseased place originated in Classical Greece rather than in medieval Europe. 7 Scholars have been equally ambivalent about hygienic standards in ancient Rome, with interpretations of written and archeological evidence alternating between construing Rome as a precursor to modern standards and an urban dystopia. ${ }^{8}$

Ancient historians' insights have yet to alter the view of the Middle Ages as anything but a uniquely backward period, a hiatus perpetuated by superstition and apathy. The enduring view partly stems from our ignorance about regional developments in the Middle Ages, but also from Protestant or anti-religious sentiments promoted or fostered by some Humanist and Enlightenment scholars. ${ }^{9}$ The latter have convinced modern audiences that uncritical early Christians took at its word St. Jerome's dictum that "he who is once washed in Christ need not wash again", and left hygiene to the heathen. Any public health concerns that medieval urban dwellers dealt with were only those forced upon them, namely leprosy and bubonic plague. In one scholar's verdict, which is still prevalent today, "the peoples of Europe emerged from the Middle Ages and came down to very modern times with no general comprehension of any one of the principles of public health". 10

The continuing tyranny of ameliorist views in the historiography of public health misrepresents not only the Middle Ages but later periods as well. For instance, an influential blueprint for improving US public health considers "truly radical" the idea, advocated by the 19th-century Poor Law reformer Sir Edwin Chadwick, that governments should take responsibility for "providing clean water, building sanitary sewers, [and] removing animal carcasses and other refuse". 11 Until historians of pre-modern society rise to the challenge of filling such lacunae, otherwise informed scholars will likely continue uninterrupted to air erroneous ideas grounded only in the myth of modernity, and occasionally of antiquity.

\section{Forerunners and Problems in Pre-Modern Studies}

Learned refutations of traditional narratives of progress have not been entirely absent, such as Lynn Thorndike's "Sanitation, Baths, and Street-Cleaning in the Middle Ages and Renaissance" (1928); ${ }^{12}$ and Ernest Sabine's series of detailed studies on medieval London's sanitation practices, published throughout the $1930 \mathrm{~s}^{13}$ A systematic study of 
medieval environmental control by G. T. Salusbury appeared in 1939 under the somewhat misleading title Street Life in Medieval England. ${ }^{14}$ A trickle of articles followed, demonstrating the modest but consistent scale of medieval hygienic, preventative, and public health practices. ${ }^{15}$

Real winds of change began to blow in the 1970s, also thanks to the wedding of physical anthropology and medieval archeology, and its joint offspring, paleopathology, which has done much to improve our knowledge of pre-modern diets, health, and disease. ${ }^{16}$ In parallel, Carlo Cipolla published his seminal Public Health and the Medical Profession in the Renaissance, in which he traced the professionalization of the city's medical protection. ${ }^{17}$ Subsequently, and partially inspired by Michel Foucault's work on modern hospitals, medical and institutional historians became more interested in examining their subjects hospitals and their inmates, diseases and the sick- from broader and interrelated perspectives, a trend epitomized in Katharine Park's social history of Renaissance medical practitioners, John Henderson's and Peregrine Horden's work on Byzantine and Italian hospitals, respectively, and Carole Rawcliffe's studies on English leprosaria, ${ }^{18}$ to name a few major contributions. Jointly they have placed pre-modern care and cure in their own social, scientific, political, and religious contexts without the teleological constraints that seem to have burdened many earlier scholars.

Such works have also illuminated cities' propensity for ordering their spaces and populations in ways that are not usually associated with the pre-modern period. In this sense they overlap and chime with a growing number of studies on urban minorities such as Jews, "undesirable" populations such as foreigners and criminals, social marginals such as sex workers and the elderly, and at-risk groups such as the physically impaired. ${ }^{19}$ Recent sensitivity to and interest in these groups in the pre-modern world has led to a substantial revision of their interaction with "mainstream" or "healthy" populations, which can be broadly described as a shift from rejection to containment. That cities increasingly came to terms with their diverse populations is reflected in the accommodations they made, however begrudgingly, from the creation of urban hospitals and leprosaria, to the designation of "red-light" districts, to the foundation of municipal prisons. ${ }^{20}$ Not all such initiatives were the prerogative of local governments: leprosaria, hospitals, and almshouses, for instance, were usually religious rather than civic foundations, and the work of numerous lay confraternities in Europe and of various waqf endowments in the Middle East to support at-risk populations, filled lacunae among the available social services. ${ }^{21}$ Jointly, however, secular and religious, top-down as well as grassroots action, all sought to address what was becoming a key concern of an increasingly heterogeneous society, an observation that challenges its image as one bent on identifying its inner demons and persecuting them as a mean to create a more salubrious and homogenous world. ${ }^{22}$

This complex process also contrasts with the view of pre-modern public health as predominantly a reactionary spurt to the threat of plague. ${ }^{23}$ But there are further reasons to zoom out of 1348 and the plague's subsequent visitations. For one thing, after centuries of growth, population decline probably preceded the Black Death by more than a generation, at least in some areas. ${ }^{24}$ Conversely, demographic contraction risks having a devastating effect on the urban environment, for instance, through property neglect, diminished security, and reduced access to health services. ${ }^{25}$ Thus, cities had to deal with population rise as well as its decline well before 1348, which questions the suitability of isolating that admittedly harsh period as a singularly pivotal moment in terms of public health interventions. ${ }^{26}$

Furthermore, whatever the plague prompted has been amplified by scholarship still wedded to the notion that public health is essentially occupied with epidemiology. 
Cipolla's major contributions to this field are a case in point, for they typically focus, not on the general populace, but on the medical profession and its regulation and mobilization by local governments. And while he openly advocates an environmental approach, his subjects remain diseases and physicians. ${ }^{27}$ Park's social history of the Florentine medical profession, usefully abandons a traditional focus on university-trained physicians by employing the prism of "medical practitioners" (a term favored by recent historians of gender and health). Yet her compelling study lacks a sustained discussion of population-level health measures beyond remarking on the hiring of communal doctors. ${ }^{28}$ Nonetheless, these and other studies have established solid points of departure for observing processes of urban healthscaping in pre-modernity. ${ }^{29}$

\section{Open Questions and Research Prospects}

The available literature has left a number of questions open: To what extent, for instance, were health and illness environmentally rather than clinically defined? Did certain structures of knowledge promote a view of health as the absence of disease (considered mostly a Classical definition) or rather emphasize that health depended on multiple facets of daily life (a definition associated with modernity)? And in either case, what were the implications for preventing disease and limiting its spread at a population level or fostering the most congenial environment for reducing health risks? What kinds of bodies, organizations, and individuals played a part in addressing such challenges and how, if at all, did they interact? What were the ramifications of these efforts in terms of the built environment, from private dwellings to civic architecture, and what can such healthscaping processes tell us about the relations between the private and public spheres? Did one's position along socioeconomic strata influence his or her access to the benefits of public health? Were such benefits gendered, or were they stacked against disempowered groups and marginal individuals? And how did all these aspects change over time and under different regimes? Last but not least, did any of it actually work in terms of reducing harm?

There are several ways to answer at least some of these questions. Studying doctors and other guilds, government organs, or single complex environments, can be a first step to investigating their interactions or building up to a comparative study. Documenting change over time in specific locales itself constitutes a comparative study of public-health practices in a diachronic sense. For instance, between 1000 and 1500 few if any cities in Europe and the Near East escaped a fundamental regime change, which may have led to a revision of preventive practices; and, as already mentioned, most of these regions were affected by Black Death, rendering the event a putative watershed moment in internal histories of prevention. Accordingly, comparing between cities and among groups of case studies can improve our analysis, revealing local and regional emphases and leading to the formulation of hypotheses regarding such differences.

Geopolitical diversity can likewise lend itself to a transregional investigation. In Italy, some cities became territorial states and changed their political apparatus, thereby increasing a government's degree of centralization, in which case we would expect to see some impact on the infrastructure of prevention (e.g., a more or less efficient court, the imposition of measures on subordinate territories, etc.). But was that the case when the Palestinian cities of Jerusalem, Ramlah, and eventually Acre were acquired by the Ayyubids and moved from under Byzantine rule, then from under an early Islamic one to a western Christian cultural hegemony, and then again to a Muslim one under the Mamluks? And what impact, in terms of public health, did the transition of Durëss, in 
present-day Albania, from Byzantine to Venetian rule have, or Dubrovnik's achievement of effective autonomy under the Hungarians (and later the Turks)? Similar questions could be asked for virtually every city for which enough documentation survives, raising the possibility of studying healthscaping as a process of negotiating power relations.

\section{Interdisciplinary Connections and Documents of Practice}

Implicit but never fully realized in the existing literature is the need to situate social medicine in particular and preventative healthcare generally within the framework of urbanization, social control, lay piety, gender relations, and institutional development, and trace the interplay among individual, corporate, and governmental agents. ${ }^{30}$ From a historical perspective, it is crucial in each case to establish how such developments were contingent upon local conditions within the realms of politics, science, religion, topography, and demography. Yet it is also useful to facilitate the study of conduits of public health interventions between cities and across regions all too often studied in isolation from one another. This is particularly true in the case of the Mediterranean basin, where numerous cities shared a Roman past and, by the late Middle Ages, began renewing their commercial and diplomatic ties apace. ${ }^{31}$ Detecting such conduits will in turn provide modern debates on the history of health interventions on an urban population-level with a richer and better grounded perspective.

Scholars working in several modern fields can likewise provide insights. Engaging a number of ongoing debates in urban planning, politics, social justice, gender studies, and public health, can thus augment our knowledge about the extent to which earlier governments, individuals, and organizations strove toward improving their environments, even if at times merely as extensions of themselves. ${ }^{32}$ Whatever they did, of course, lacked the kind of scientific, systematic, or statistical underpinning common to such actions today. But, however under- or misinformed, and contrary to much received wisdom on the matter, such attempts can be traced in the available records dating to well before the early modern period.

Until recently scholars have mostly privileged prescriptive and normative texts over descriptive and practical ones as evidence for preventative action in pre-modern societies. Consequently our knowledge of attempts to improve public health was derived mainly from sources such as law codes, building manuals, medical treatises, or occasionally citycouncil minutes, usually at the expense of account books, tax records, diaries, letters, and court protocols. Taking medical practitioners and urban officials at their word, however, undermined any potential argument about the actual development of public health measures, since it refrained from connecting law with (in this case, preventative) action, despite numerous sources available for such purposes. Not surprisingly, scholars have tended to vacillate between branding governments' mobilization of resources to such ends as an utter failure and celebrating their triumph in attaining the instructions handed down by physicians, lawyers, and architects. "Straws in the wind" was the simile chosen by the US authors of the only monograph on the subject in order to describe failed top-down attempts to adjust the environment of Italian cities to the challenges at hand, while the very same normative sources were used to draw quite different conclusions by other contemporary Italian scholars. ${ }^{33}$

Achieving a critical distance from the prescripts of medieval legislators and doctors is therefore crucial for improving our knowledge of public health practices. Broadly speaking, there are two ways to do so. The first is to develop and apply new methodologies to familiar sources. As Monica Green, Michael Solomon, and others have shown, both 
normative and scientific treatises can be subjected to readership studies with great profit, allowing us to observe the impact of such texts on and their appropriation by a growing audience of non-medical consumers. ${ }^{34}$ The method has the advantage of allowing individuals and not only governments and highly learned individuals to tell the story, which at least has the merit of offering a new albeit equally subjective perspective.

A second option is to expand the evidentiary basis by consulting documents and instruments of practice, from extant city-council minutes to the remains of public latrines, and ask what they can tell us about pre-modern realities and attitudes. To offer one example, the archives of some Italian cities, including Lucca and Bologna, contain the records of local curie viarum, effectively environmental courts, predating the onset of the plague at least by several decades. ${ }^{35}$ The officers in charge of these bodies were often concerned with enforcing sanitary and building regulations, hearing complaints from residents about pertinent violations, interviewing witnesses, and fining offenders for their violations: men and women occupying public ways illicitly for industrial or commercial purposes, landlords directing their gutters at public spaces, domestic servants blocking sewage canals with waste, and rural communes neglecting to maintain public facilities such as bridges, gates, and roads.

The extant registers attest not only environmental concerns but also enforcement activities. They also reveal that complaints could be made publicly, for instance by neighbors and at court, and that the officials entertained secret accusations as well as made their own in situ inquiries. Those familiar with the London Assize of Nuisance, also dating to the same period, will immediately recognize the parallels, and how useful they can be for discerning tensions between legislation and enforcement, ideas, and practice. ${ }^{36}$ But compared with the London records, the Italian records are much more numerous as well as virtually untapped, suggesting the tip of a documentary iceberg. Furthermore, as Spanish historian Luis García-Ballester has shown, parallel court cases exist from early 14th-century Aragon, ${ }^{37}$ and given the fast transmission of governmental practices among Italian cities and between them and their southern French, northern Spanish, and Mediterranean counterparts, more local archives are bound to yield similar records.

Other European regions look similarly promising. The Dubrovnik State Archives hold a series on Sanitas dating back to the 13th century, which suggests that perhaps other port cities in the region (e.g., Zadar and Split), pursued similar policies. And it goes almost without saying that numerous Dutch and Belgian cities are particularly rich in pertinent sources. Outside of Europe, waqf records especially from the Mamluk period, as well as various documents conserved by Jewish and Islamic Genizas throughout the Middle East are likely to supply many new details regarding public-health measures. ${ }^{38}$ Jointly these and other records may tell us much about preventive awareness and practices in pre-modern times.

\section{Further Pathways}

Tracing processes of healthscaping through medieval documents of practice is not always possible, even as the archival efforts of social, architectural, religious, and medical historians continue to provide invaluable insights. ${ }^{39}$ Accordingly there is a need to identify alternative paths, such as studying literary and especially material evidence, in order to round out the picture and document - wherever possible - how preventive measures were employed (or rejected, or abandoned, or altered), and how they were perceived and experienced by contemporaries.

Art and literature provides one such pathway, affording us views of pre-modern hygienic practices and norms, the transformation of metaphors for cleanliness, health, and 
purity, the valorizing or promotion of efforts to address pollution and contagion, and descriptions of diets and environments and their relations with physical and mental wellbeing. ${ }^{40}$ This is especially true in the case of the Mamluk and Byzantine empires, which left relatively few documents of practice but rather abundant literary sources such as chronicles, fables, and poetry. Also extant from these regions are underutilized normative sources such as administrative guides and monastic rules, which often contain a wealth of information about hygiene, diet, and disease. ${ }^{41}$ In sum, the interplay between texts, spaces, artifacts, and images is bound to cast much further light on pre-modern healthscaping.

Part and parcel of a multidisciplinary approach to the history of public health is an attempt to engage material culture through archeology, both of architectural structures and of human remains. The former allows us to trace and analyze physical interventions in urban sites and the general application (or lack) of public health measures, such as situating cesspits and leprosaria downwind, and operating quarantine facilities outside a city's gates or port. Examples of both categories are to be found, for instance, in Dubrovnik, home to both a magnificent fountain, explicitly built and located at one of the city's main entrances for hygienic purposes, and one of the earliest documented quarantine sites in Europe (see Figs 1-2).

Paleopathology, or the medical study of ancient human remains and deposits, such as graveyards and cesspits, can also help draw connections between health concerns (such as feeding) and interventions in a very direct way. And, needless to say, cemeteries and

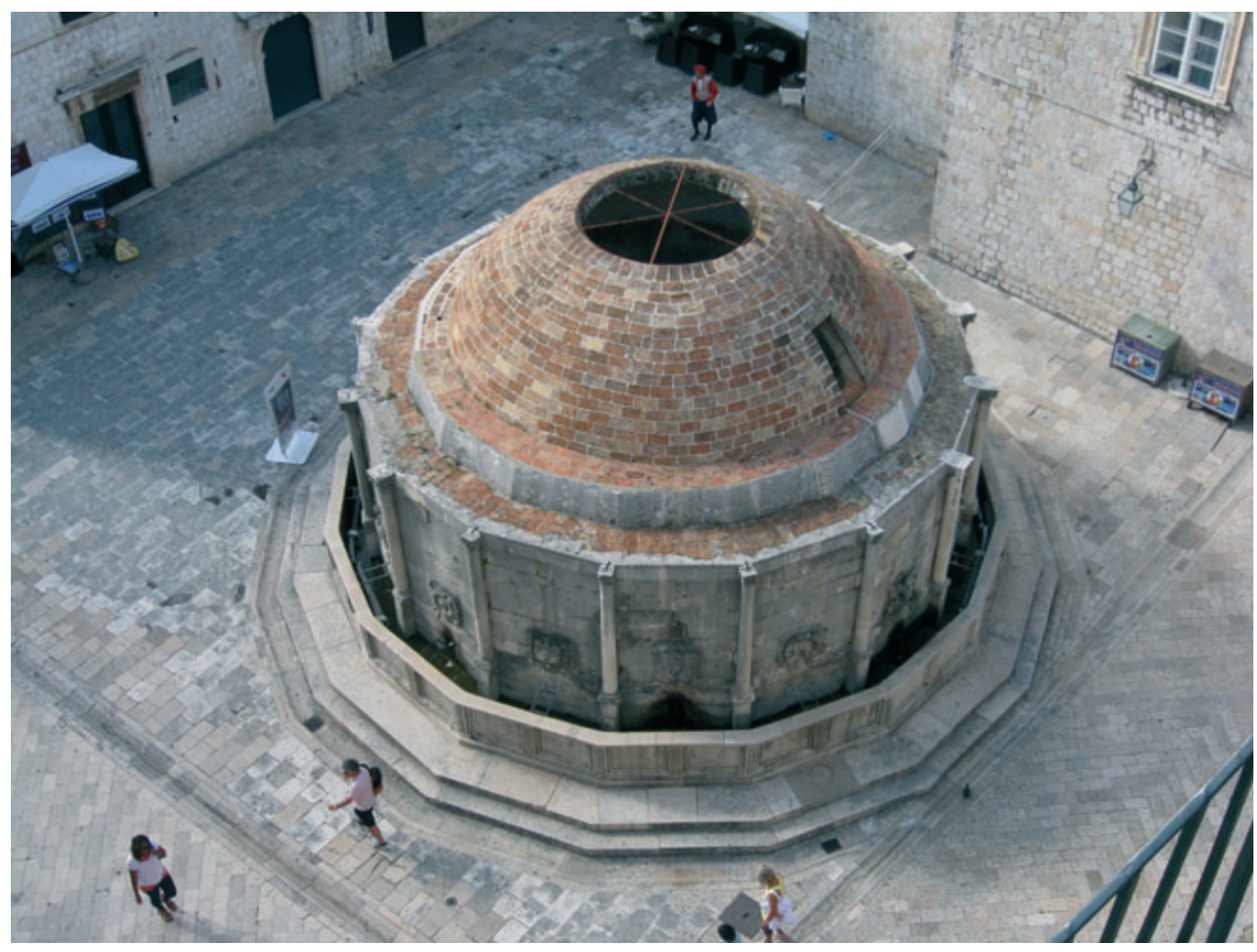

Fig 1. Onofrio's Great Fountain (1438). 


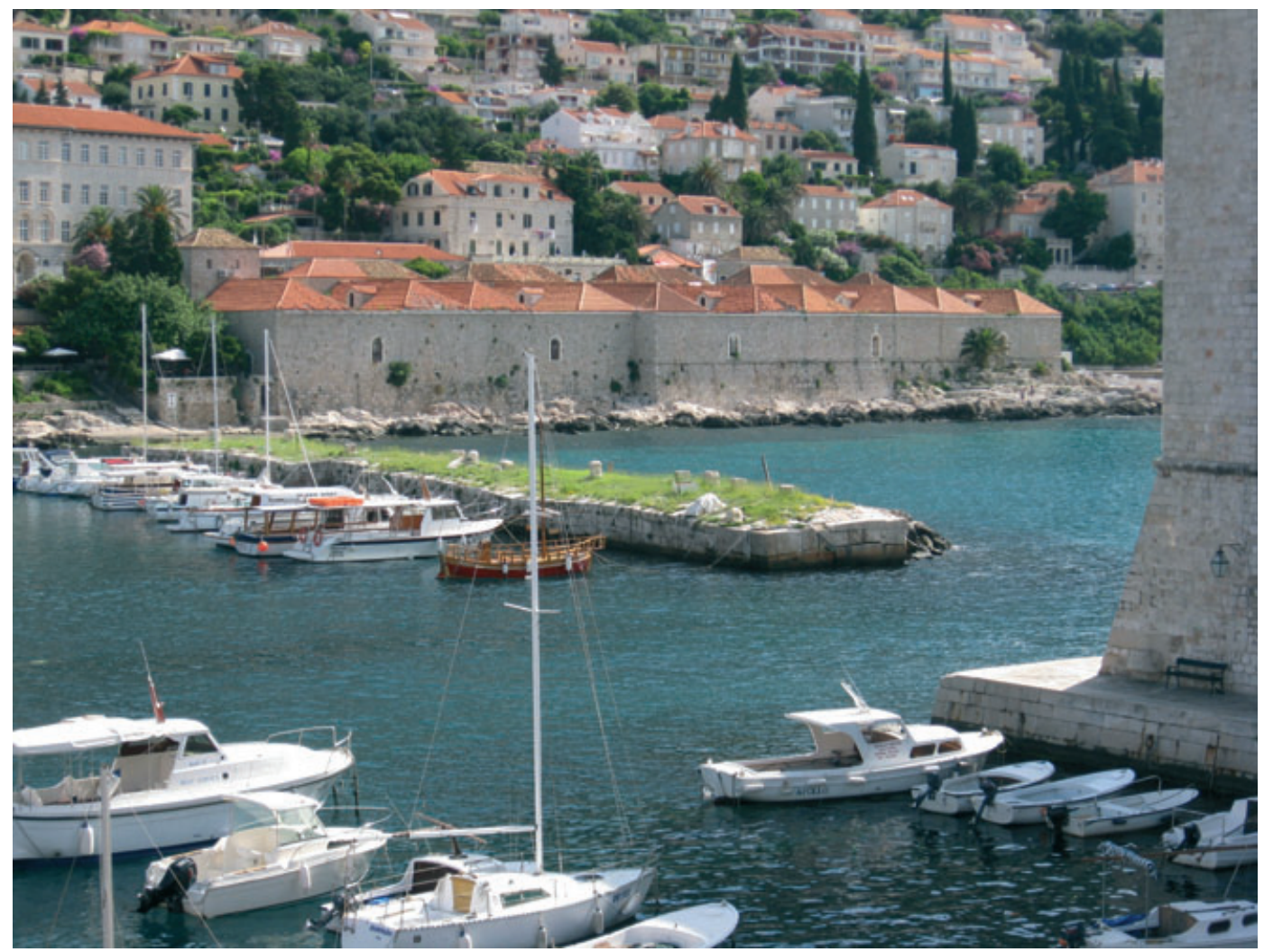

Fig 2. Quarantine facility (c. 1377).

other repositories are themselves a rich source of information about diseases as well as environmental waste management and its relations with religious practices. ${ }^{42}$ Both intentionally and inadvertently, archeologists have been at the forefront of gathering information about urban public health for many decades, and it is crucial to harness their efforts, as well as those of others exploring different kinds of material evidence, to paint clearer local, regional, and transregional pictures.

Last, writing the history of pre-modern urban public health can also be borne of a dia$\log$ with a range of current debates and should thus be done in a conscious attempt to contribute back to them. Providing modern public health professionals with a historical perspective tests the common assumption that successful interventions (i.e., effecting behavioral change) are contingent upon the existence of central government action, advanced technology, and modern science. Did pre-modern population-level initiatives outperform the development of medical care and rising access to it? And if so, what are the implications from the combined perspective of health and social justice? Answers to such questions would contribute to modern discussion, which are often woefully disengaged from historical insight.

\section{Acknowledgement}

My thanks to Maaike van Berkel and the anonymous reviewers for History Compass. I dedicate this paper to the participants of my first graduate seminar on pre-modern public 
health at the University of Amsterdam: Janna Coomans, Hidde van Eijk, Marianne Elsakkers, Martje aan de Kerk, Rob van Lieshout, and Daniëlle van Mourik. It was thanks to their hard work and relentless interrogation of sources, sites, and instructor that this survey came into being.

\section{Short Biography}

G. Geltner is Professor of Medieval History and Director of the Center for Medieval Studies Amsterdam. He is broadly interested in the themes of order and disorder, especially in the pre-modern urban context.

\section{Notes}

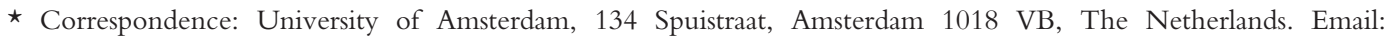
g.geltner@uva.nl.

1 G. Burke, Towns in the Making (London: Edward Arnold, 1971), 60-2 (emphasis mine).

2 G. Sjoberg, The Preindustrial City: Past and Present (New York: The Free Press, 1960), 94.

3 P. Crone, Pre-Industrial Societies (Oxford: Basil Blackwell, 1989), 156-9.

${ }^{4}$ G. Rosen, A History of Public Health, revised edition (Baltimore: Johns Hopkins University Press, 1993), 56.

${ }^{5}$ S. K. Cohn, Jr., Cultures of Plague: Medical Thinking at the End of the Renaissance (Oxford: Oxford University Press, 2010), 239. See also Ann G. Carmichael, Plague and the Poor in Renaissance Florence (Cambridge: Cambridge University Press, 1986).

6 J. Longrigg, 'Death and Epidemic Disease in Classical Athens', in V. M. Hope and E. Marshall (eds.), Death and Disease in the Ancient City (London: Routledge, 2000), 55-64.

7 J. Clark Kosak, 'Polis nosousa. Greek Ideas about the City and Disease in the Fifth Century BC', in Hope and Marshall (eds.), Death and Disease in the Ancient City, 35-54.

8 N. Morley, 'The Salubriousness of the Roman City', in H. King (ed.), Health in Antiquity (London and New York: Routledge, 2005), 192-204.

9 O. P. Grell and A. Cunningham (eds.), Health Care and Poor Relief in Protestant Europe, 1500-1700 (London and New York: Routledge, 1997), 3. But see J. Israel, 'Dutch Influence on Urban Planning, Health Care and Poor Relief: The North Sea and the Baltic Regions of Europe, 1567-1720', ibid., 66-83; B. Pullan, 'Support and Redeem: Charity and Poor Relief in Italian Cities from the 14th to the 17th Century', Continuity and Change, 3 (1988): 177-208; D. J. Constantelos, Byzantine Philanthropy and Social Welfare, 2nd edn. (New Rochelle, NY: Caratzas, 1991); A. Sabra, Poverty and Charity in Medieval Islam: Mamluk Egypt, 1215-1517 (Cambridge: Cambridge University Press, 2000).

${ }_{10}$ C.-E. A. Winslow, The Evolution and Significance of the Modern Public Health Campaign (New Haven, CT: Yale University Press, 1923), 6. And see P. M. Hohenberg and L. Hollen Lees, The Making of Urban Europe, 1000-1950 (Cambridge, MA: Harvard University Press, 1985), 132; G. Vigarello, Concepts of Cleanliness: Changing Attitudes in France since the Middle Ages, trans. J. Birrell (Cambridge and New York: Cambridge University Press, 1988), $142-55$.

${ }^{11}$ T. Farley and D. A. Cohen, Prescription for a Healthy Nation: A New Approach to Improving our Lives by Fixing our Everyday World (Boston: Beacon Press, 2005), 27.

${ }^{12}$ L. Thorndike, 'Sanitation, Baths, and Street-Cleaning in the Middle Ages and Renaissance', Speculum, 3 (1928): 192-203.

13 E. L. Sabine, 'Butchering in Mediaeval London', Speculum, 8 (1933): 335-53; idem, 'Latrines and Cesspools of Mediaeval London', Speculum, 9 (1934): 303-21; idem, 'City Cleaning in Mediaeval London', Speculum, 12 (1937): $19-43$.

${ }^{14}$ G. T. Salusbury, Street Life in Medieval England (Oxford: Pen-in Hand, 1939).

15 R. Loewe, 'Handwashing and the Eyesight in the Regimen Sanitatis', Bulletin of the History of Medicine, 30 (1956): 100-8; D. Jarry, 'Diététique et hygiène au XIIIe et XIVe siècle', Languedoc Medical, 41 (1958): 5-24.

16 For example, D. J. Keene, 'Rubbish in Medieval Towns', in A. R. Hall and H. K. Kenward (eds.), Environmental Archaeology in the Urban Context (London: Council for British Archaeology, 1982), 26-30; M. McCormick, 'Rats, Communications, and Plague: Toward an Ecological History', Journal of Interdisciplinary History, 34 (2003): 1-25; M. Jansen, 'Water Supply and Sewage Disposal at Mohenjo-Daro', World Archaeology, 21 (1989): 177-92; M. M. Lahr and J. E. Bowman, 'Paleopathology of the Kechipawan Site: Health and Disease in a Southwestern Pueblo', Journal of Archaeological Science, 19 (1992): 639-54; C. Bourbou, Health and Disease in Byzantine Crete (7th-12th centuries AD) (London: Ashgate, 2010). 
17 C. M. Cipolla, Public Health and the Medical Profession in the Renaissance (Cambridge: Cambridge University Press, 1976).

18 K. Park, Doctors and Medicine in Early Renaissance Florence (Princeton, NJ: Princeton University Press, 1985); J. Henderson, The Renaissance Hospital: Healing the Body and Healing the Soul (New Haven, CT: Yale University Press, 2006); P. Horden, 'The Earliest Hospitals in Byzantium, Western Europe, and Islam', Journal of Interdisciplinary History, 35 (2005): 361-89; idem, Hospitals and Healing from Antiquity to the Later Middle Ages (Aldershot, UK: Ashgate, 2008); C. Rawcliffe, Medicine and Society in Later Medieval England (Stroud, UK: Alan Sutton, 1995); idem, Leprosy in Medieval England (London: Boydell, 2006). And see T. S. Miller, The Birth of the Hospital in the Byzantine Empire (Baltimore and London: The Johns Hopkins University Press, 1985); S. Sweetinburgh, The Role of the Hospital in Medieval England: Gift-Giving and the Spiritual Economy (Portland, OR: Four Courts Press, 2004); S. Watson, 'The Origins of the English Hospital', Transactions of the Royal Historical Society, 6th series, 16 (2006): 75-94.

19 I. Metzler, Disability in Medieval Europe: Thinking about Physical Impairment during the High Middle Ages, c. 11001400 (London and New York: Routledge, 2006).

20 G. Geltner, The Medieval Prison: A Social History (Princeton, NJ: Princeton University Press, 2008).

21 N. Terpstra, Lost Girls: Sex and Death in Renaissance Florence (Baltimore, MD: The Johns Hopkins University Press, 2010); S. Farmer, Surviving Poverty in Medieval Paris: Gender, Ideology, and the Daily Lives of the Poor (Ithaca and London: Cornell University Press, 2002); Sabra, Poverty and Charity in Medieval Islam.

22 N. Cohn, Europe's Inner Demons (St. Albans: Paladin, 1976); J. Boswell, Christianity, Social Tolerance, and Homosexuality (Chicago, IL: University of Chicago Press, 1981); R. I. Moore, The Formation of a Persecuting Society: Power and Deviance in Western Europe, 950-1250 (Oxford: Basil Blackwell, 1987).

23 Cipolla, Public Health and the Medical Profession, 11; idem, Miasmi ed umori: ecologia e condizioni sanitarie in Toscana nel Seicento (Bologna: Il Mulino, 1989), 2; Horden, 'The Earliest Hospitals in Byzantium, Western Europe, and Islam'; A. Kinzelbach, 'Infection, Contagion, and Public Health in Late Medieval German Imperial Towns', Journal of the History of Medicine and Allied Sciences, 61 (2006): 369-89; R. A. Olea and G. Christakos, 'Duration of Urban Mortality for the 14th-century Black Death Epidemic', Human Biology, 77 (2005): 291-303; J. M. Theilmann and F. Cate, 'A Plague of Plagues: The Problem of Plague Diagnosis in Medieval England', Journal of Interdisciplinary History, 37 (2007): 371-93.

24 A. I. Pini, 'Problemi di demografia bolognese del Duecento', Atti e memorie della Deputazione di Storia Patria per le Provincie di Romagna, n.s. 17-19 (1965-68): 147-222.

25 D. J. Keene, Survey of Medieval Winchester (Oxford: Clarendon Press, 1985), 53.

26 D. Balestracchi, 'The Regulation of Public Health in Italian Medieval Towns', in H. Hundsbichler, G. Jaritz and T. Kühtreiber (eds.), Die Vielfalt der Dinge: Neue Wege zur Analyse mittelaltericher Sachkultur (Vienna: Verlag der Österreichischen Akademie der Wissenschaften, 1998), 356.

27 Cipolla, Public Health and the Medical Profession, 32. And see idem, Miasmi e umori, 10-26.

28 Park, Doctors and Medicine. And see T. Dean (ed. and trans.), The Towns of Italy in the Later Middle Ages (Manchester: Manchester University Press, 2000), 56-58.

29 D. Little, 'The Nature of the Khaqahs, Ribats and Zawiyas under the Mamluks', in W. B. Hallaq and D. Little (eds.), Islamic Studies Presented to Charles J. Adams (Leiden: Brill, 1991), 91-105; L. Chipman, The World of Pharmacy and Pharmacists in Mamluk Cairo (Leiden: Brill, 2009); P. Pormann, 'Islamic Medicine Crosspollinated: A Multilingual and Multiconfessional Maze', in J. Montgomery, A. Akasoy and P. E. Pormann (eds.), Islamic Crosspollinations: Interactions in the Medieval Middle East (Cambridge: The E. J. W. Gibb Memorial Trust, 2007), 76-91.

${ }^{30}$ See J. M. Theilmann, 'The Regulation of Public Health in Late Medieval England', in J. L. Gillespie (ed.), The Ages of Richard II (Stroud: Sutton, 1997), 205-23.

31 F. Braudel, La Méditerranée et le monde méditerranéen à l'époque de Philippe II (Paris: Colin, 1949); P. Horden and N. Purcell, The Corrupting Sea: A Study of Mediterranean History (Oxford: Blackwell, 2000), 123-72; C. Wickham, Framing the Early Middle Ages: Europe and the Mediterranean, 400-800 (Oxford: Oxford University Press, 2005), 591-831.

32 Farley and Cohen, Prescription for a Healthy Nation; M. G. Fissell, 'Introduction: Women, Health and Healing in Early Modern Europe', Bulletin of the History of Medicine, 82 (2008): 1-17; M. H. Green, 'Gendering the History of Women's Healthcare', Gender \& History, 20 (2008): 487-518.

33 R. E. Zupko and R. A. Laures, Straws in the Wind: Medieval Urban Environmental Law; The Case of Northern Italy (Boulder, CO: Westview Press, 1996); F. Bocchi, 'Regulation of the Urban Environment by the Italian Communes from the Twelfth to the Fourteenth Century', Bulletin of the John Rylands Library, 72 (1990): 63-78; R. Greci, 'Il problema dello smaltimento dei rifuiti nei centri urbani dell'Italia medievale', in Città e servizi sociali nell'Italia dei secoli XII-XV (Pistoia: Centro Italiano di Studi di Storia e d'Arte Pistoia, 1990), 458-60. See also B. S. Hakim, Arabic-Islamic Cities. Building and Planning Principles (London: Kegan Paul, 1986); idem, 'Mediterranean Urban and Building Codes: Origins, Content, Impact, and Lessons', Urban Design International, 13 (2008): 21-40.

34 M. H. Green, Making Women's Medicine Masculine: The Rise of Male Authority of Pre-Modern Gynaecology (New York: Oxford University Press, 2008); M. Solomon, Fictions of Well-Being: Sickly Readers and Vernacular Medical Writing in Late Medieval and Early Modern Spain (Philadelphia, PA: University of Pennsylvania Press, 2010). 
35 S. R. Blanshei, Politics and Justice in Late Medieval Bologna (Leiden: Brill, 2010), 516-17; G. Geltner, 'Healthscaping a Medieval City: The Curia viarum of Lucca in the Fourteenth Century' (forthcoming).

${ }^{36}$ H. M. Chew and W. Kellaway (eds.), London Assize of Nuisance 1301-1431 - A Calendar (London: London Record Society, 1973).

37 'The Construction of a New Form of Learning and Practicing Medicine', Science in Context, 8 (1995): 90-1.

38 F. Bauden, 'Mamluk Era Documentary Studies: The State of the Art', Mamlūk Studies Review, 9 (2005): 15-60; M. M. Amin, Al-Awqâf wa-l-hayât al-ijtimâ'iyya fì Misr, 648-923 H./1250-1517 M. (Cairo: Dar al-Nahdha al-Arabiyya, 1980); S. D. Goitein, A Mediterranean Society: The Jewish Communities of the Arab World as Portrayed in the Documents of the Cairo Geniza, 6 vols. (Berkeley, CA: The University of California Press, 1967-93), 5:94-103; Sabra, Poverty and Charity, 69-100; Cohen, "Geniza for Islamicists, Islamic Geniza, and the "New Cairo Geniza", Harvard Middle Eastern and Islamic Review, 7 (2006): 129-45.

39 M. H. Green, 'Medicine in the Archives: Resources for Researching Medical History Topics', Medieval Feminist Forum, 40 (2005): 60-7, 83-6; idem and D. Lord Smail, 'The Case of Floreta d'Ays (1403): Jews, Christians, and Obstetrics in later Medieval Marseilles', Journal of Medieval History, 34 (2008): 185-211.

${ }^{40}$ J. K. Hyde, 'Medieval Descriptions of Cities', Bulletin of the John Rylands Library, 48 (1966): 308-40; G. Fasoli, 'La coscienza civica nelle "Laudes civitatum",, in La coscienza cittadina nei comuni italiani del Duecento (Todi: Accademia Tedertina, 1972), 9-44; A. P. Coudert, 'Sewers, Cesspools, and Privies: Waste as Reality and Metaphor in Pre-Modern European Cities', in A. Classen (ed.), Urban Space in the Middle Ages and the Early Modern Period (Berlin and New York: Walter de Gruyter, 2009), 713-33; E. Cockayne, Hubbub: Filth, Noise E Stench in England, 1600-1770 (New Haven and London: Yale University Press, 2007).

41 A. al-Rahmaan b. Nasr al-Shayzari, The Book of the Islamic Market Inspector. Nihayat al-Rutba fi Talab al-Hisba (The Utmost Authority in the Pursuit of Hisba), trans. R. P. Buckley (Oxford: Oxford University Press, 1999); Byzantine Monastic Foundation Documents: A Complete Translation of the Surviving Founders' Typika and Testaments, ed. J. Thomas and A. Constantinides Hero; with the assistance of G. Constable; trans. R. Allison, et al., 5 vols. (Washington, DC: Dumbarton Oaks Research Library and Collection, 2000).

42 C. Daniell, Death and Burial in Medieval England, 1066-1550 (London and New York: Routledge, 1997); Jansen, 'Water Supply and Sewage Disposal at Mohenjo-Daro', 177-92; D. Jørgensen, 'Cooperative Sanitation: Managing Streets and Gutters in Late Medieval England and Scandinavia', Technology and Culture, 49 (2008): 547-67; Keene, 'Rubbish in Medieval Towns'; Olea and Christakos, 'Duration of Urban Mortality'; J. M. Rogers, 'Sāmarrā: A Study in Medieval Town-Planning', in A. Hourani and S. M. Stern (eds.), The Islamic City: A Colloquium (Oxford: Bruno Cassirer, 1970), 119-55; T. Waldron, 'The Effects of Urbanisation on Human Health: The Evidence from Skeletal Remains', in D. Serjeantson and T. Waldron (eds.), Diet and Craft in Towns: The Evidence of Animal Remains from the Roman to the Post-Medieval Periods (Oxford: British Archaeological Reports, 1989), $55-73$.

\section{Bibliography}

Amin, M. M., Al-Awqâf wa-l-hayât al-ijtimâ'iyya fî Misr, 648-923 H./1250-1517 M (Cairo: Dar al-Nahdha al-Arabiyya, 1980).

Balestracci, D., 'The Regulation of Public Health in Italian Medieval Towns', in H. Hundsbichler, G. Jaritz and T. Kühtreiber (eds.), Die Vielfalt der Dinge: Neue Wege zur Analyse mittelaltericher Sachkultur (Vienna: Verlag der Österreichischen Akademie der Wissenschaften, 1998), 345-57.

Barefoot, P., 'Buildings for Health. Then and Now', in H. King (ed.), Health in Antiquity (London and New York: Routledge, 2005), 205-15.

Bauden, F., 'Mamluk Era Documentary Studies: The State of the Art', Mamlūk Studies Review, 9 (2005): 15-60.

Bériou, N., and Touati, F.-O., Voluntate Dei Leprosus. Les Lépreux entre conversion et exclusion aux XIIIème et XIIIème siècles (Spoleto: Centro Italiano di Studi sull'Alto Medioevo, 1991).

Blanshei, S. R., Politics and Justice in Late Medieval Bologna (Leiden: Brill, 2010).

Bocchi, F., 'Regolamenti urbanistici, spazi pubblici, disposizioni antinquinamento e per l'igiene nelle maggiori città della Sardegna medievale', in La Corona d'Aragona in Italia (secc. XIII-XVIII) (Pisa: ETS, 1995), II.1, $73-124$.

Bocchi, F., 'Regulation of the Urban Environment by the Italian Communes from the Twelfth to the Fourteenth Century', Bulletin of the John Rylands Library, 72 (1990): 63-78.

Bonine, M. E., 'Waqf and its Influence on the Built Environment of the Medina of the Islamic Middle Eastern City', in A. Classen (ed.), Urban Space in the Middle Ages and the Early Modern Period (Berlin and New York: Walter de Gruyter, 2009), 615-44.

Bourbou, C., Health and Disease in Byzantine Crete (7th-12th centuries AD), Medicine in the Medieval Mediterranean 1 (London: Ashgate, 2010).

Braudel, F., La Méditerranée et le monde méditerranéen à l'époque de Philippe II (Paris: Colin, 1949).

Braunfels, W. (trans. Kenneth J. Northcott), Urban Design in Western Europe: Regime and Architecture, 900-1900 (Chicago, IL: University of Chicago Press, 1990). 
Brundage, J. A., 'Let me Count the Ways: Canonists and Theologians Contemplate Coital Positions', Journal of Medieval History, 10 (1984): 81-93.

Bulst, N., and Delort, R. (eds.), Maladies et société (XIIe-XVIIIe siècles), Actes du colloque de Bielefeld, novembre 1986 (Paris: CNRS, 1989).

Byzantine Monastic Foundation Documents: A Complete Translation of the Surviving Founders' Typika and Testaments, J. Thomas and Constantinides Hero, A. (eds.), with the assistance of G. Constable (trans. R. Allison), et al., 5 vols. (Washington, DC: Dumbarton Oaks Research Library and Collection, 2000).

Carmichael, Ann G., Plague and the Poor in Renaissance Florence (Cambridge: Cambridge University Press, 1986).

Cavallo, S., and Gentilcore, D. (eds.), Spaces, Objects and Identities in Early Modern Italian Medicine (Oxford: Blackwell, 2008).

Chipman, L., The World of Pharmacy and Pharmacists in Mamluk Cairo (Leiden: Brill, 2009).

Cipolla, C. M., Fighting the Plague in Seventeenth-Century Italy (Madison, WI: University of Wisconsin Press, 1981).

Cipolla, C. M., Miasmi ed umori: ecologia e condizioni sanitarie in Toscana nel Seicento (Bologna: Il Mulino, 1989).

Cipolla, C. M., Public Health and the Medical Profession in the Renaissance (Cambridge, UK and New York: Cambridge University Press, 1976).

Città e servizi sociali nell'Italia dei secoli XII-XV (Pistoia: Centro Italiano di Studi di Storia e d'Arte Pistoia, 1990).

Cockayne, E., Hubbub: Filth, Noise \& Stench in England, 1600-1770 (New Haven, CT, and London: Yale University Press, 2007).

Cohen, M. R., Poverty and Charity in the Jewish Community of Medieval Egypt (Princeton, NJ: Princeton University Press, 2005).

Cohn, S. K. Jr., Cultures of Plague: Medical Thinking at the End of the Renaissance (Oxford: Oxford University Press, 2010).

Conklin, B. A., “"Thus are Our Bodies, Thus was Our Custom”, American Ethnologist, 22 (1995): 76-102.

Constantelos, D. J., Byzantine Philanthropy and Social Welfare, 2nd edn. (New Rochelle, NY: Caratzas, 1991).

Coudert, A. P., 'Sewers, Cesspools, and Privies: Waste as Reality and Metaphor in Pre-Modern European Cities', in A. Classen (ed.), Urban Space in the Middle Ages and the Early Modern Period (Berlin and New York: Walter de Gruyter, 2009), 713-33.

Daniell, C., Death and Burial in Medieval England, 1066-1550 (London and New York: Routledge, 1997).

Dols, M. W., The Black Death in the Middle East (Princeton, NJ: Princeton University Press, 1977).

Dols, M. W., Majnūn: The Madman in Medieval Islamic Society, D. E. Immisch (ed.). (Oxford: Clarendon Press, 1992).

Drossbach, G. (ed.), Hospitäler in Mittelalter und früher Neuzeit: Frankreich, Deutschland und Italien (Munich: R. Oldenbourg, 2007).

Dumas, R., Histoire des hôpitaux Saint-Eloi et Gui de Chauliac à Montpellier (Montpellier: Sauramps médical, 2005).

Duri, A. A., 'Governmental Institutions', in R. B. Serjeant (ed.), The Islamic City (Paris: Unesco, 1980), 52-65.

Écochard, M., and Le Coeur, C., Les bains de Damas, 2 vols. (Beirut: Institut français de Damas, 1942-43).

Elsakkers, M., 'Reading between the Lines: Old Germanic and Early Christian Views on Abortion', PhD Thesis, University of Amsterdam, 2010.

Farley, T., and Cohen, D. A., Prescription for a Healthy Nation: A New Approach to Improving our Lives by Fixing our Everyday World (Boston: Beacon Press, 2005).

Farmer, S., Surviving Poverty in Medieval Paris: Gender, Ideology, and the Daily Lives of the Poor (Ithaca and London: Cornell University Press, 2002).

Fasoli, G., 'La coscienza civica nelle "Laudes civitatum"”, in La coscienza cittadina nei comuni italiani del Duecento (Todi: Accademia Tedertina, 1972), 9-44.

Fissell, M. G., 'Introduction: Women, Health and Healing in Early Modern Europe', Bulletin of the History of Medicine, 82 (2008): 1-17.

Frier, B. W., 'Natural Fertility and Family Limitation in Roman Marriage', Classical Philology, 89 (1994): 318-33.

García-Ballester, L., 'The Construction of a New Form of Learning and Practicing Medicine in Medieval Latin Europe', Science in Context, 8 (1995): 75-102.

Geltner, G., The Medieval Prison: A Social History (Princeton, NJ: Princeton University Press, 2008).

Goitein, S. D., A Mediterranean Society: The Jewish Communities of the Arab World as Portrayed in the Documents of the Cairo Geniza, 6 vols. (Berkeley, CA: The University of California Press, 1967-93).

Green, M. H., 'Gendering the History of Women's Healthcare', Gender \& History, 20 (2008): 487-518.

Green, M. H., 'Integrative Medicine: Incorporating Medicine and Health into the Canon of Medieval European History', History Compass, 7 (2009): 1218-45.

Green, M. H., Making Women's Medicine Masculine: The Rise of Male Authority of Pre-Modern Gynaecology (New York, NY: Oxford University Press, 2008).

Green, M. H., 'Medicine in the Archives: Resources for Researching Medical History Topics', Medieval Feminist Forum, 40 (2005): 60-7, 83-6.

Green, M. H., and Lord Smail, D., 'The Case of Floreta d'Ays (1403): Jews, Christians, and Obstetrics in later Medieval Marseilles', Journal of Medieval History, 34 (2008): 185-211. 
Grell, O. P., and Cunningham, A. (eds.), Health Care and Poor Relief in Protestant Europe, 1500-1700 (London and New York: Routledge, 1997).

Grigsby, B. L., 'Medical Misconceptions', in Stephen J. Harris and Bryon L. Grigsby (eds.), Misconceptions about the Middle Ages (New York and London: Routledge, 2008), 142-50.

Guillerme, A. E., The Age of Water: The Urban Environment in the North of France, A.D. 300-1800 (College Station, TX: Texas A\&M University Press, 1988).

Hakim, B. S., Arabic-Islamic Cities. Building and Planning Principles (London: Kegan Paul, 1986).

Hakim, B. S., 'Mediterranean Urban and Building Codes: Origins, Content, Impact, and Lessons', Urban Design International, 13 (2008): 21-40.

Hardon, A., and Mahidon, M., Applied Health Research Manual: Anthropology of Health and Health Care, 3rd edn., revised (Amsterdam: Het Spinhuis, 2001).

Harris, W. V., 'Child Exposure in the Roman Empire', The Journal of Roman Studies, 84 (1994): 1-22.

Hecht, J., 'From "Be Fruitful and Multiply" to Family Planning: The Enlightenment Transition', Eighteenth-Century Studies, 32 (1999): 536-51.

Henderson, J., 'The Parish and the Poor in Florence at the Time of the Black Death: The Case of S. Frediano', Continuity and Change, 3 (1988): 247-72.

Henderson, J., The Renaissance Hospital: Healing the Body and Healing the Soul (New Haven, CT: Yale University Press, 2006).

Hohenberg, P. M., and Hollen Lees, L., The Making of Urban Europe, 1000-1950 (Cambridge, MA: Harvard University Press, 1985).

Hope, V. M., and Marshall, E. (eds.), Death and Disease in the Ancient City (London: Routledge, 2000).

Hopkins, K., 'Contraception in the Roman Empire', Comparative Studies in Society and History, 8 (1965-66): 12451.

Horden, P., 'The Earliest Hospitals in Byzantium, Western Europe, and Islam', Journal of Interdisciplinary History, 35 (2005): 361-89.

Horden, P., Hospitals and Healing from Antiquity to the Later Middle Ages (Aldershot, UK: Ashgate, 2008).

Horden, P., and Purcell, N., The Corrupting Sea: A Study of Mediterranean History (Oxford: Blackwell, 2000).

Hughes, J. D., Pan's Travail: Environmental Problems of the Ancient Greeks and Romans (Baltimore, MD: Johns Hopkins University Press, 1994).

Humphreys, R. S. (eds.), 'Urban Topography and Urban Society: Damascus under the Ayyubids and Mamluks', in Islamic History: A Framework for Inquiry, revised edn. (Princeton, NJ: Princeton University Press, 1991), $209-32$.

Hyde, J. K., 'Medieval Descriptions of Cities', Bulletin of the John Rylands Library, 48 (1966): 308-40.

Jansen, M., 'Water Supply and Sewage Disposal at Mohenjo-Daro', World Archaeology, 21 (1989): 177-92.

Jarry, D., 'Diététique et hygiène au XIIIe et XIVe siècle', Languedoc Medical, 41 (1958): 5-24.

Jørgensen, D., 'Cooperative Sanitation: Managing Streets and Gutters in Late Medieval England and Scandinavia', Technology and Culture, 49 (2008): 547-67.

Karras, R. Mazo, 'The Regulation of Brothels in Later Medieval England', Signs: Journal of Women in Culture and Society, 14 (1989): 399-433.

Karras, R. Mazo, 'Women's Labors: Reproduction and Sex Work in Medieval Europe', Journal of Women's History, 15 (2004): 153-8.

Keene, D. J., 'Rubbish in Medieval Towns', in A. R. Hall and H. K. Kenward (eds.), Environmental Archaeology in the Urban Context (London: Council for British Archaeology, 1982), 26-30.

Kinzelbach, A., 'Infection, Contagion, and Public Health in Late Medieval German Imperial Towns', Journal of the History of Medicine and Allied Sciences, 61 (2006): 369-89.

Lahr, M. M., and Bowman, J. E., 'Paleopathology of the Kechipawan Site: Health and Disease in a Southwestern Pueblo', Journal of Archaeological Science, 19 (1992): 639-54.

Little, D., 'The Nature of the Khaqahs, Ribats and Zawiyas under the Mamluks', in W. B. Hallaq and D. Little (eds.), Islamic Studies Presented to Charles J. Adams (Leiden: Brill, 1991), 91-105.

Loewe, R., 'Handwashing and the Eyesight in the Regimen Sanitatis', Bulletin of the History of Medicine, 30 (1956): 100-8.

Magherini, G., and Biotti, V. L'Isola delle Stinche e i percorsi della follia a Firenze nei secoli XIV-XVIII (Florence: Ponte alle Grazie, 1992).

Magnusson, R. J., Water Technology in the Middle Ages: Cities, Monasteries, and Waterworks after the Roman Empire (Baltimore and London: The Johns Hopkins University Press, 2001).

Marcuse, P. et al. (eds.), Searching for the Just City: Debates in Urban Theory and Practice (London and New York: Routledge, 2009).

Martin, J.-M. (ed.), Bains curatifs et bains hygiéniques en Italie de l'Antiquité au Moyen Age (Rome: École francaise de Rome, 2007).

McCormick, M., 'Rats, Communications, and Plague: Toward an Ecological History', Journal of Interdisciplinary History, 34 (2003): 1-25.

Meyer, A., and Schulz-Grobert, Jürgen (eds.), Gesund und krank im Mittelalter (Leipzig: Eudora Verlag, 2007). 
Miller, T. S., The Birth of the Hospital in the Byzantine Empire (Baltimore, MD, and London: The Johns Hopkins University Press, 1985).

Miller, T. S., The Orphans of Byzantium: Child Welfare in the Christian Empire (Washington, DC: The Catholic University of America Press, 2003).

Mollat, M. (trans. Arthur Goldhammer), The Poor in the Middle Ages: An Essay in Social History (New Haven, CT, and London: Yale University Press, 1986).

Morley, N., 'The Salubriousness of the Roman City', in H. King (ed.), Health in Antiquity (London and New York: Routledge, 2005), 192-204.

Muller, C., Gerichtspraxis im Stadtstaat Cordoba: Zum Recht der Gesellschaft in einer malikitisch-islamischen Rechtstradition des 5.11. Jahrhunderts (Leiden: Brill, 1999).

Müller, W. P., 'Canon Law versus Common Law: The Case of Abortion in Late Medieval England', in Kenneth Pennington, Stanley Chodorow and Keith H. Kendall (eds.), Proceedings of the Tenth International Congress of Medieval Canon Law (Syracuse N.Y., 13-18 August 1996) (Vatican City: Biblioteca Apostolica Vaticana, 2001), 92941.

Nichols, D. L., and Charlton, T. H. (eds.), The Archaeology of City-States: Cross-Cultural Approaches (Washington, DC: Smithsonian Institution Press, 1997).

Noonan, J. T. Jr., Contraception; a History of its Treatment by the Catholic Theologians and Canonists, enlarged edition (Cambridge, MA: Harvard University Press, 1986).

Olea, R. A., and Christakos, G., 'Duration of Urban Mortality for the 14th-century Black Death Epidemic', Human Biology, 77 (2005): 291-303.

Park, K., Doctors and Medicine in Early Renaissance Florence (Princeton, NJ: Princeton University Press, 1985).

Pini, A. I., 'Problemi di demografia bolognese del Duecento', Atti e memorie della Deputazione di Storia Patria per le Provincie di Romagna, n.s. 17-19 (1965-68): 147-222.

Pormann, P., 'Islamic Medicine Crosspollinated: A Multilingual and Multiconfessional Maze', in J. Montgomery, A. Akasoy and P. E. Pormann (eds.), Islamic Crosspollinations: Interactions in the Medieval Middle East (Cambridge: The E. J. W. Gibb Memorial Trust, 2007), 76-91.

Porter, D. (ed.), A History of Public Health and the Modern State (Amsterdam and Atlanta: Editions Rodopi, 1994).

Pullan, B., 'Support and Redeem: Charity and Poor Relief in Italian Cities from the 14th to the 17th Century', Continuity and Change, 3 (1988): 177-208.

Rawcliffe, C., Leprosy in Medieval England (London: Boydell, 2006).

Rawcliffe, C., Medicine and Society in Later Medieval England (Stroud, UK: Alan Sutton, 1995).

Riccetti, L., "'Per havere dell'acqua buona per bevere." Orvieto: città e cantieri del duomo, secoli XIV-XV', Nuova rivista storica, 78 (1994): 241-92.

Riddle, J. M., Contraception and Abortion from the Ancient World to the Renaissance (Cambridge, MA: Harvard University Press, 1992).

Riddle, J. M., Eve's Herbs: A History of Contraception and Abortion in the West (Cambridge, MA: Harvard University Press, 1997).

Rogers, J. M., 'Sāmarrā: A Study in Medieval Town-Planning', in A. Hourani and S. M. Stern (eds.), The Islamic City: A Colloquium (Oxford: Bruno Cassirer, 1970), 119-55.

Rosen, G., The History of Public Health, revised edn. (New York: MD Publications, 1958).

Sabine, E. L., 'Butchering in Mediaeval London', Speculum, 8 (1933): 335-53.

Sabine, E. L., 'City Cleaning in Mediaeval London', Speculum, 12 (1937): 19-43.

Sabine, E. L., 'Latrines and Cesspools of Mediaeval London', Speculum, 9 (1934): 303-21.

Sabra, A., Poverty and Charity in Medieval Islam: Mamluk Egypt, 1215-1517 (Cambridge: Cambridge University Press, 2000).

Salusbury, G. T., Street Life in Medieval England (Oxford: Pen-in Hand, 1939).

Scanlon, G. T., 'Housing and Sanitation: Some Aspects of Medieval Islamic Public Service', in A. Hourani and S. M. Stern (eds.), The Islamic City: A Colloquium (Oxford: Bruno Cassirer, 1970), 179-94.

Shatzmiller, J., Jews, Medicine and Medieval Society (Berkeley, CA: University of California Press, 1994).

al-Shayzari, A. al-Rahmaan b. Nasr (trans. R. P. Buckley), The Book of the Islamic Market Inspector. Nihayat al-Rutba fi Talab al-Hisba (The Utmost Authority in the Pursuit of Hisba) (Oxford: Oxford University Press, 1999).

Sheard, S., and Power, H. (eds.), Body and City: Histories of Urban Public Health (Aldershot, UK: Ashgate, 2000).

Sjoberg, G., The Preindustrial City: Past and Present (New York: The Free Press, 1960).

Solomon, M., Fictions of Well-Being: Sickly Readers and Vernacular Medical Writing in Late Medieval and Early Modern Spain (Philadelphia, PA: University of Pennsylvania Press, 2010).

Stearns, J., 'New Directions in the Study of Religious Responses to the Black Death', History Compass, 7 (2009): $1363-75$.

Steckel, R. H., 'New Light on the "Dark Ages"”, Social Science History, 28 (2004): 211-29.

Stillman, N., 'Charity and Social Service in Medieval Islam', Societas, 5 (1975): 105-15.

Stilt, K. A., 'Regulating Medieval Cairo', in F. Daftary, E. Fernea and A. Nanji (eds.), Living in Historic Cairo: Past and Present in an Islamic City (Seattle, WA: University of Washington Press, 2010), 62-70. 
Sweetinburgh, S., The Role of the Hospital in Medieval England: Gift-Giving and the Spiritual Economy (Portland, OR: Four Courts Press, 2004).

Terpstra, N., Lost Girls: Sex and Death in Renaissance Florence (Baltimore, MD: The Johns Hopkins University Press, 2010).

Theilmann, J. M., 'The Regulation of Public Health in Late Medieval England', in J. L. Gillespie (ed.), The Ages of Richard II (Stroud: Sutton, 1997), 205-23.

Theilmann, J. M., and Cate, F., 'A Plague of Plagues: The Problem of Plague Diagnosis in Medieval England', Journal of Interdisciplinary History, 37 (2007): 371-93.

Thorndike, L., 'Sanitation, Baths, and Street-Cleaning in the Middle Ages and Renaissance', Speculum, 3 (1928): 192-203.

Vigarello, G. (trans. Jean Birrell), Concepts of Cleanliness: Changing Attitudes in France since the Middle Ages (Cambridge: Cambridge University Press, 1988).

Waldron, T., 'The Effects of Urbanisation on Human Health: The Evidence from Skeletal Remains', in D. Serjeantson and T. Waldron (eds.), Diet and Craft in Towns: The Evidence of Animal Remains from the Roman to the Post-Medieval Periods (Oxford: British Archaeological Reports, 1989), 55-73.

Watson, S., 'The Origins of the English Hospital', Transactions of the Royal Historical Society, 6th series, 16 (2006): 75-94.

Wickham, C., Framing the Early Middle Ages: Europe and the Mediterranean, 400-800 (Oxford: Oxford University Press, 2005).

Winslow, C.-E. A., The Evolution and Significance of the Modern Public Health Campaign (New Haven, CT: Yale University Press, 1923).

Ziegler, P., The Black Death (Harmondsworth: Penguin Books, 1981).

Zupko, R. E., and Laures, R. A., Straws in the Wind: Medieval Urban Environmental Law (Boulder, CO: Westview, 1996). 